\title{
THE DIFFERENTIAL IMPACT OF THE INTERNET ON SPURRING REGIONAL ENTREPRENEURSHIP*
}

\section{Entrepreneurship Theory and Practice, forthcoming}

\author{
Douglas Cumming \\ Associate Professor and Ontario Research Chair \\ Schulich School of Business \\ York University \\ 4700 Keele Street \\ Toronto, Ontario \\ M3J 1P3 \\ Email: Douglas@Cumming.com \\ Web: http://ssrn.com/author=75390 \\ http://Douglas.Cumming.com
}

\author{
Sofia Johan \\ University of Tilburg \\ Center for Business Law \\ Postbus 90153 \\ 5000 LE Tilburg \\ The Netherlands \\ Tel: +31(0)13466 3607 \\ Fax: +31(0)13466 2323 \\ Web : http://ssrn.com/author=370203 \\ Email: sofiajohan@email.com
}

This Draft: 5 December 2008

* We are particularly indebted to Tabinda Peracha, Hui Wang and Li Que for helpful research assistance. We received helpful comments from the ISB Emerging Regions Conference (2006) and the Academy of Management Annual Conference (2007). A shortened version of this paper appeared in the Academy of Management Best Paper Proceedings (2007). Financial assistance from the Social Sciences and Humanities Research Council of Canada is gratefully acknowledged. Any errors and/or omissions are our own. 


\title{
The Differential Impact of the Internet on Spurring Regional Entrepreneurship
}

\begin{abstract}
This paper studies the effect of the introduction of government provided Internet technology to rural communities on regional entrepreneurship. Entrepreneurship increases among larger Internet communities, as the Internet spurs entrepreneurial activities by enabling agglomeration across areas that have a pre-existing cluster of real entrepreneurial activities. However, there is a decrease in entrepreneurship among smaller and more geographically remote Internet communities, as the Internet facilitates the consumption of items and services not produced within such smaller local communities. Overall, virtual entrepreneurial clusters are not independent of real entrepreneurial clusters.
\end{abstract}




\section{Introduction}

The Internet facilitates the transmission of information, culture, and economic exchange (Friedman, 2005; Gordon, 2000). And, over time, the Internet is increasingly penetrating rural economies. This penetration in many countries is facilitated largely by governmental subsidies (e.g., in Australia see http://web1.ruralbroadband.com.au/; in the U.S., see Goolsbee \& Guryan, 2005). To date, though, there has been a comparative dearth of empirical entrepreneurship research on the effect of introducing Internet technology on rural entrepreneurship. Such an effect would be expected in view of the fact that knowledge transmission and communication infrastructure are important to entrepreneurship (e.g., Audretsch, 2007a,b). But any such effect is not obvious. Rural economies that receive Internet access may develop an agglomeration economy and entrepreneurial cluster, but they also may lose as local producers face greater competition. This topic is of significant practical importance to firms, consumers, and policymakers alike, and to the study of both real and virtual entrepreneurial clusters.

Our paper is related to a few recent papers that have examined the role of the Internet in economic exchange. Haltiwanger, Jarmin, \& Schank (2003) analyze productivity changes surrounding the use of new technologies such as the Internet. Prieger (2003) documents the availability of broadband in terms of the supply side of the market. Varian (2002) analyzes transactions and economic exchange over the Internet, as well as the demand for the Internet. McKnight \& Cukor (2001) discuss the role of the Internet in facilitating knowledge networks and economic development, but do not provide any empirical analysis. Goolsbee \& Guryan (2005) and Brown \& Goolsbee (2002), respectively, examine the effect of the Internet on public schools and on market competitiveness in the life insurance industry. Castells (2001) more generally examines the effect of the Internet on society. Our paper contributes to the literature by providing theory and evidence for the impact on rural versus urban entrepreneurship of government provided Internet service on a region-wide basis. 
Roads, canals, railroads, electricity, telegraph, telephone, and television were all major infrastructure projects that had a large impact on entrepreneurship (Audretsch, 2007a,b; Chandler, 2006). Access to capital and education likewise has facilitated regional development (Audretsch, 2007a,b; Naudé, Gries, Wood, \& Meintjies, 2008), as has technological entrepreneurship (Audresch \& Feldman; 1996a, 1996b; Feldman \& Audretsch, 1999; Venkataraman, 2004; Tan, 2006; Devereux, Griffith \& Simpson, 2004). But little prior work provides a direct link between the Internet and regional entrepreneurship. Our paper fills this gap.

Specifically, we ask: What effect does the introduction of government provided Internet technology to rural communities have on regional entrepreneurship? Is there a differential impact across rural communities depending on their size and remoteness? Using a natural experiment of government provided broadband service to very remote communities, and comprehensive rural community-level data, this paper develops new hypotheses and provides empirical tests to answer these questions. The theory and evidence highlight substantial differences in the impact of the Internet on regional entrepreneurship depending on community size and remoteness.

\section{Theoretical Background and Previous Research}

At a broad level, this paper is related to studies on the impact of analysis-governmentstimulation-programs on private real investments for rural communities. There is a more general literature related to policies for entrepreneurship or economic development in rural regions (OECD, 1998). Regionally remote and smaller firms may face problems of access to capital and access to customers caused by market failure based on distance and by information asymmetries

faced by suppliers and customers. Government intervention programs therefore are often targeted to smaller firms and to regionally remote firms. One rationale for this is that the social rate of return to subsidizing small and remote firms is greater than the private rate of return (Cressy, 
2002), because the development of rural economies provides benefits to smaller communities that are not captured by immediate suppliers and by customers of the firms receiving assistance. Particularly in the high-tech sectors, policy makers around the world have become increasingly concerned about their success and have established government support programs to stimulate venture capital financing of innovative ideas and thus to foster economic growth (OECD, 1996). Small high-tech companies contribute significantly to innovation and economic growth (Acs \& Audretsch, 1987). Because there are broader returns to the development of an innovative society, the returns to innovation are not fully captured by the innovating entrepreneurs and their investors.

There is a growing literature on agglomeration economies and entrepreneurial clusters. The Internet represents a significant innovation in relation to rural entrepreneurship: it may present easier access to customers and/or suppliers, which in practice reduces the hampering effects of distance. The Internet also may provide more efficient access to information, and therefore knowledge. Knowledge and learning are both crucial elements of agglomeration economies and business clusters. For instance, it has been shown that being located in an agglomeration rich in knowledge resources is more conducive to firm growth than being located in a region that is less endowed with knowledge resources (Audretsch \& Dohse 2007). We may expect, therefore, that broad band Internet access will have an effect in relation to knowledge as well as to distance/peripherality that is related to agglomeration theory.

In addition to agglomeration theory, there are a number of alternative theoretical perspectives on the topic of the Internet and regional entrepreneurship, including evolutionary theory (Aldrich, 1990) and knowledge spillover theory (Audretsch and Keilbach, 2008). In the literature on entrepreneurship and regional development (see, e.g., Audretsch, 2007a,b; Audretsch \& Keilbach, 2007; Audretsch, Keilbach \& Lehmann, 2006; Davidsson \& Wiklund, 2001), the Internet plays an important role. And, a growing literature on the role of the Internet in rural development provides both theory and evidence that participation in the Internet is more likely in 
rural areas than in urban areas (Forman, Goldfarb, \& Greenstein, 2002). Sinai \& Waldfogel (2004) also show that people are more likely to connect to the Internet in smaller markets in order to overcome local isolation. Further, in the context of this evidence, an evolutionary perspective would arguably posit a more pronounced role for the Internet in economies that are more geographically remote. Similarly, knowledge spillover theory would predict that the Internet facilitates transmission of knowledge that otherwise might have taken a greater amount of time to reach a rural community.

Despite its potential benefits, the Internet may produce additional costs for small firms in remote regions including, for example, an increase in potential competitors if the firms in question compete in local markets. Internet consumers are less restricted in terms of buying from local suppliers. In short, the Internet has limits in terms of fostering entrepreneurship and/or economic development. Moreover, one might expect the increase in investment to be dissimilar across industries (Steinle \& Schiele, 2002). Industries whose consumers are more inclined towards online purchases (such as books and music) would give rise to greater competition for local suppliers. Industries whose firms benefit from increased access to knowledge via the Internet (including various high-tech industries) would mean that the Internet has the potential to help local firms.

\section{Research Context}

In this section we explain the institutional context in which we study the impact of the Internet on regional entrepreneurship. One of the worlds' first widespread deliveries of the Internet to rural communities across an entire provincial region took place in Canada. In November 2000, the government of the province of Alberta announced plans to build the "SuperNet”: state-of-the art Internet access for rural communities in Alberta $\quad$ (at a cost of approximately US\$150 million; http://www.albertasupernet.ca/). The SuperNet was provided to 
411 rural communities and 4,700 community institutions (380 communities will not receive the SuperNet).

Alberta is a particularly interesting forum for analysis of the role of the Internet in rural entrepreneurship. There are only two cities in the province with approximately one million residents (in 2000): Calgary and Edmonton, which are approximately 300 kilometers apart. All other communities have fewer than 100,000 residents. Edmonton, the second largest city in the province, is Canada’s most northerly (among cities with more than 100,000 residents). Extremely vast distances separate the other communities in the province. The geographic remoteness and ruggedness of the province is perhaps best exemplified by those familiar with the popular movies “Mystery Alaska” (1999) and “Brokeback Mountain” (2005), which were filmed in Canmore and other areas in Alberta (with the intention of representing a town in Alaska and the geography of Wyoming, respectively). In essence, the remoteness of communities in the province makes the introduction of broadband Internet access a notable event for them, one worthy of further study.

The intention of the SuperNet was to: “...focus on the people of Alberta, and the places they conduct government business, learn, receive health care and connect with their communities. Alberta SuperNet provides the foundation to help Albertans benefit from and participate in the knowledge economy. These benefits - in our schools, health facilities, libraries and in the provision of provincial and municipal government services - will be particularly evident in rural Alberta communities, where high-speed access has been so much more limited than in urban areas.” [source: http://www.albertasupernet.ca/]

It is important to note that the SuperNet communities were not awarded access on the basis of economic need but rather on the basis of linking publicly funded institutions (this is a crucial fact for the structure of the empirical tests that we carried out, in the sense that Internet adoption is not endogenous as in Forman, Goldfarb \& Greenstein, 2005). Nevertheless, an anticipated side benefit of the SuperNet was the entrepreneurial development it was expected to bring to the communities that were awarded access: "As a side effect of connecting all schools, 
hospitals, libraries and government offices, the face of business in rural Alberta communities will change, with the business development opportunities that exist with access to high-speed, broadband. Opportunities for high-speed access for home-based and commercial businesses will increase as commercial service providers use the network to expand service offerings.” [source: http://www.albertasupernet.ca/]

In short, while an anticipated side effect of the SuperNet was an increase in entrepreneurial development in rural communities, the communities that were 'awarded' the SuperNet were not identified on the basis of economic need. Rather, communities were awarded the SuperNet if they met certain criteria that included minimum standards for community hospitals, schools, libraries, and provincial government offices (“community institutions”); the same set of standards was applied to all communities. Communities that did not meet these exogenously established standards were not allocated a SuperNet connection, because the objective was to link these publicly funded institutions. The way in which the SuperNet was brought into the rural communities provides social scientists with a unique forum, analogous to a laboratory environment, or a "natural experiment”, to assess the role of the Internet in society.

\section{Hypotheses}

Based on the research context and prior literature discussed above, in this section we develop and summarize the testable hypotheses. It is natural to expect Alberta's SuperNet community members to benefit from enhanced education, health, library, and governmental services. However, the 'side effect' on the rural economy from the introduction of the SuperNet is less clear. The effect on the SuperNet on entrepreneurship in rural communities is not obvious, because of the shift of production and consumption decisions. On one hand, rural businesses may expand their production to take advantage of opportunities via the SuperNet, such as increased access to social and knowledge networks not previously available to these Albertan communities 
(Van Geenhuizen, 2008). On the other hand, rural businesses may face increasing global competition as rural consumers gain access to products and services offered over the Internet (Friedman, 2005). If so, investment in rural production opportunities may, in fact, decline in conjunction with the introduction of broadband Internet into rural communities.

Note that costs and pricing are not expected to be primary drivers of entrepreneurial activities associated with the SuperNet. The cost of using the SuperNet in rural communities is regulated by the government in a way that makes rates comparable to those in urban communities. The SuperNet allows existing and new Internet Service Providers (ISPs) access to the network at competitive rates. Fair access to the extended area is guaranteed for all interested ISPs. In turn, these ISPs will be able to make residential and business high-speed Internet services available at competitive (urban) rates. The SuperNet is designed to be self-sustaining. Revenue collected is used for operational costs and capital maintenance on the entire system on a shared basis (http://www.albertasupernet.ca/).

While the SuperNet primarily is being used to link the community institutions and improve communication between the residents of the rural communities, with the potential side benefit of entrepreneurial development that comes from increased access to knowledge and social networks, such connectivity may not be enough to promote entrepreneurship within smaller and more remote SuperNet communities (see e.g., Feldman, 2001; Couclelis, 2004; Malecki, 2004). Internet access quickly increases the breadth of a firm's competitive environment as geographic location becomes less of a barrier to knowledge acquisition and communication (see e.g., Litan \& Rivlin, 2001). As such, we expect cost-inefficient smaller rural communities facing increasing competition via the Internet to experience comparatively less entrepreneurship and real investment.

Further, such a reduction in real investment among smaller remote communities might be a catalyst for entrepreneurship and agglomeration in larger remote communities (see e.g., Saxenian, 1996; Venkataraman, 2004). Sinai \& Waldfogel (2004) show that for users, the 
Internet is a substitute for cities. It is possible to deduce that such connectivity will successfully help the rural communities to overcome local isolation but that it will not be sufficient for users to have the Internet substitute for the social and economic interaction of cities. Thus, real “substitute cities” potentially will be created, with the concentration of entrepreneurship in the larger SuperNet communities that are geographically remote from the two largest urban centers in Alberta, Calgary and Edmonton. The potential for agglomeration as a result of the transfer of investments or resources will expand production within the larger SuperNet communities, as they are seen to be more efficient from various perspectives, such as proximity to consumers (Hotelling, 1929; Smithies, 1941) and external economies (Krugman, 1991). Similarly, Forman, Goldfarb and Greenstein (2006) find that firms will invest more in locations with higher density.

Further, knowledge spillover theory (Audretsch \& Keilbach, 2008) is consistent with the view that the Internet is not by itself sufficient for eliminating the importance of physical location for entrepreneurship. Knowledge spillovers will retain their geographic component or locational importance in that the SuperNet mainly will encourage entrepreneurial activities and enable agglomeration across areas with a pre-existing (pre-SuperNet) cluster of non-virtual or real entrepreneurial activities. Marshall (1890) provided the basis of research on location, innovation and agglomeration effects. Furman, Kyle, Cockburn \& Henderson (2008) find that local knowledge spillovers, at least in the pharmaceutical industry, are twice as large on a local basis. Forman, Goldfarb, \& Greenstein (2002) find that the importance of location is not eliminated with the use of the Internet. Audretsch \& Dohse (2007) further emphasize the economic value of location in accessing entrepreneurship knowledge and resources.

A lower cost system for trading services, such as via the Internet, favors diversified cities (Anas \& Xiong, 2003). We expect to be able to identify the potential for a system of diversified agglomerated “substitute cities”, which may attract entrepreneurship and real investments within the region, in addition to supporting the two large urban cities, Calgary and Edmonton. Proximity is essential for agglomeration and to sustain the virtuous cycle as communities benefit from 
access-spillover from investments (both in real and more intangible terms), and the interaction between people, institutions, and firms (see e.g., Venkataraman, 2004; Braunerhjelm \& Borgman, 2006; West, Bamford \& Marsden, 2008). Proximity is also an essential determinant of the transfer of wealth as investors face a trade-off between various forms of increasing returns and different types of mobility costs (see e.g., Fujita \& Thisse, 2002). Hence, the Internet increases the propensity for agglomeration in more geographically remote yet populous communities (Venkataraman, 2004; Mason \& Harrison, 2002).

Overall, therefore, based on the prior literature, we expect the relationship between SuperNet access and new entrepreneurial investment to depend critically on existing conditions that promote entrepreneurial and technology clusters, such as density. We further expect the relationship between SuperNet access and new entrepreneurial investment to depend on geographic proximity to larger communities. We therefore formulate the following hypotheses that distinguish the effects of size and geographical remoteness.

Hypothesis 1 [Size]: A government funded regional Internet project will stimulate entrepreneurship in larger rural communities, but discourage entrepreneurship in smaller rural communities.

Hypothesis 2 [Distance]: A government funded regional Internet project will encourage entrepreneurship in geographically remote communities, potentially initiating agglomeration.

Taken together, Hypotheses 1 and 2 imply that smaller, geographically remote communities will experience less entrepreneurial activity with the introduction of the Internet, while other larger communities with a pre-existing cluster will experience greater entrepreneurial activity with the introduction of the Internet. One interesting question arising from Hypotheses 1 
and 2 is whether the communities that gain will outweigh the communities that lose. Because one of the fundamental economic principles is that exchange makes transacting parties better off (e.g., Marshall, 1990), and that the Internet facilitates exchange, we would expect the Internet to increase entrepreneurial activity in gaining communities more than it discourages entrepreneurial activity in losing communities.

Hypothesis 3 [Overall Effect]: On average, regional communities that do not receive access to a government funded regional Internet project will experience comparatively less new entrepreneurship relative to communities provided with Internet access.

In sum, we expect a relative decline in entrepreneurship among smaller geographically remote SuperNet communities, a relative increase in entrepreneurship in larger geographically remote communities, and an overall increase in entrepreneurship. The next sections of the paper provide empirical tests of these three propositions.

\section{Methods}

The SuperNet project was announced to all communities in the province on the same date: November 2000. Our focus is on comparing proxies for entrepreneurial activity before and after this announcement date, even though construction of the SuperNet was not completed until 2006. The focus on the announcement date is based on the idea that long-term investment decisions are made in terms of the expected delivery of the SuperNet, (with negligible risk of non-delivery, as it was a guaranteed governmental expenditure). Our focus is on five calendar years, 1999 - 2003. This enables us to analyze entrepreneurial activities in communities before the SuperNet, and a comparison to a subsequent time frame. 
In this study, we consider real private investment expenditures a proxy for entrepreneurial activities and the benefit (or costs) of the Internet to a community. For the purposes of this paper, real investment is defined as all non-financial investment, such as investment in assets, buildings, etc., and private investment is defined as non-governmental real investment. Our measure of investment is the best possibly proxy for community-wide economic benefits, and is viewed as one of the most important indicators by Alberta Economic Development (2005). Our measure also enables control variables for a number of factors, including industry variables, as we discuss below.

We focus on real investment expenditure, not on firm births or deaths, because such measures do not take into account investment activities by existing firms (i.e., entrepreneurial activities within pre-existing firms). Previous literature on entrepreneurship at the regional level often has used business entries and exits as the measure of entrepreneurship (e.g., Reynolds, Storey \& Westhead, 1994), while the literature on regional economic development often has used more macroeconomic measures. Measures of entrepreneurial activity, such as firm births or deaths, do not account for changes in investment activity by existing firms in the community; macroeconomic measures tend to be less precise than our investment measure. Our measure of investment is the best possibly proxy for community-wide economic benefits. Furthermore, the provincial statisticians view investment activities as the most important indicator of economic and entrepreneurial activity (Alberta Department of Economic Development, 2005). In some cases, investment projects spanned more than one community. There are spillover benefits to a local community generally when firms are better off (or potentially worse off, depending on the costs relative to the benefits). If a project was listed as being located in more than one community, then the benefit of that project (i.e. dollar value of investment) is allocated to both the county and municipal district based on the following formula: [Cost of project] / [\# of municipalities listed]. Overall, for the issues addressed in this paper, the investment data are more appropriate than firm births-deaths as a dependent variable. 
Our dependent variable for private investments is not directly related to the building of the SuperNet as such (i.e., the cost of putting in the lines; the demand on construction firms) as these expenditures are not included in our dependent variable. Note too that we checked whether the rollout schedule to build the SuperNet affected the results. In theory, this is irrelevant because planned major construction projects would be made with the expectation of the SuperNet being introduced in the community (as a government guarantee). We still checked for the robustness of our results to differences across communities in terms of when they received a SuperNet line. Those robustness checks did not indicate material changes to the quantitative results reported herein. Similarly, other robustness checks were considered (such as numbers of projects, subsets of industries, etc.), and they did not affect the conclusions from the data reported. Note too that to the extent that projects are indirectly related to the SuperNet, the data overstate the degree to which SuperNet communities experience higher investment levels. In other words, a finding that SuperNet communities exhibit lower investment levels would be understated. But we do not expect this to be a major issue, because the amounts involved would be small, and we assess robustness to different project sizes.

The variables used in the empirical analysis are defined in Table 1 . The province records all investment projects across all industries in all communities in their database, Inventory of Major Alberta Projects, and Inventory of Alberta Regional Projects. Projects are recorded as purely private investment, purely public investment, and private/public partnership investment. Projects are broadly construed to include all industries, ranging from technology development to building construction. Projects are recorded by the time of planning and completion. The data represent the majority of construction projects in Alberta. In order to assess the timing of planning and completion of projects, the government contacts and follows-up on projects with companies, as well as obtaining access to building permits and checking media sources regarding these projects. Projects are separated into the following categories: agriculture; chemicals and petrochemicals (involves manufacturing products/petrochemicals in a facility); commercial/retail; 
forestry; infrastructure (part of basic framework in the province that must be in place before a community can start, e.g. roads, bridges, police/fire stations, waste water treatment, storm sewers, etc.; institutional (things that benefit the public and are part of the social fabric of the community, e.g., schools, hospitals, courthouses, churches); manufacturing; mining; oil and gas (including mining and extracting from the ground); pipelines; power; residential; telecommunications; and tourism and recreation. Every project is listed with a detailed description in the source data from the Alberta Department of Economic Development (2005).

\section{[Table 1 About Here]}

To control for differences between SuperNet and non-SuperNet communities, we control for a number of factors. Explanatory variables used in the analyses include both demographic variables and prior investment variables. Demographic variables are: a dummy variable equal to one for non-SuperNet communities, a variable for the population in the community, and a variable that indicates the shortest driving distance from the Calgary. Calgary is the largest city and the economic hub of the Province. A variable indicating the driving distance from Edmonton (the second largest city) is not used, because it is highly correlated with the driving distance from Calgary. The exclusion of either the Calgary or Edmonton distance variable was irrelevant for the data analysis and results; therefore, we excluded the Edmonton variable to avoid collinearity.

We use the distance of 150 kilometres from the major cities, Edmonton and Calgary, as a basis for "remoteness". Alberta covers a massive geographic area within Canada and the communities awarded the SuperNet span the entire region. Edmonton and Calgary are, however, the only cities with more than 100,000 residents. Those two cities are 300 kilometres apart; therefore, it is instructive to use the 150-kilometer cutoff level, because virtually all of those who work in Calgary or Edmonton will commute from a distance of less than 150 kilometers (the 
average commuting time in Alberta is 22 minutes per day; http://www.pembina.org/pdf/publications/22.Commuting.pdf).

The prior-investment variables are: prior planned private investment and prior planned public and public/private investment. Hence, projects that were contemplated before the SuperNet announcement are not reflected in the dependent variable. Rather, they are explanatory variables, because prior investment decisions may affect future decisions, particularly for the years immediately preceding the investment decisions. We also include as explanatory variables : prior completed private, public, and private/public investment projects. Some investment projects span a few years, and the recently completed projects in communities may naturally affect new investment decisions made in such communities.

We note that increases in private investments across communities possibly could be related to factors other than Internet access. For instance, there could be efforts undertaken by the community to reach the minimum standards for community hospitals, schools, etc. in order to receive SuperNet. However, in our analyses we control for different types of industries, and our findings are robust to various methods (both reported and otherwise, and additional specifications are available upon request from the authors). Further, hospitals and schools are public expenditures in Canada (or possibly private/public), and our analyses explicitly control for public and private expenditures.

As discussed earlier, one anticipated side effect of the SuperNet project was increasing entrepreneurship in rural and less populous communities; however, communities that received SuperNet access were not identified on the basis of economic need. Rather, SuperNet communities were identified on the basis of linking community institutions. In effect, the SuperNet is a natural experiment for comparing investment expenditures in SuperNet versus nonSuperNet communities. Because the government awarded the SuperNet to communities on a basis other than economics, there is no endogeneity concern with respect to analyzing the effect of its introduction on private investment in rural communities. 


\section{Summary Statistics}

Raw summary statistics for all of the data, and for all of the communities in the Province whether or not they were awarded the SuperNet (801 communities), are provided in Table 2. It shows that the total value of minor and major private projects (that is, non-governmental projects) for any given community after the SuperNet announcement comprise on average was Can\$300,000 and Can\$10,150,000, respectively. Median project levels for any given community are zero, which fits with the median level of 177 persons. Non-SuperNet communities comprise $49 \%$ of the sample. Investment levels prior to the SuperNet announcement were higher than after the SuperNet announcement (reflecting general economic conditions in 2001-3 relative to 1999 and 2000). Private investment levels are notably higher than public/private and purely public investment levels, as indicated in Table2).

[Table 2 About Here]

Table 3 Panel A presents comparison tests for the full sample of 411 SuperNet communities relative to the 390 non-SuperNet communities. The comparison tests in Panel A indicate that SuperNet communities overall enjoyed higher levels of private investment for both minor and major projects. Prior to the SuperNet, the differences between the communities are not statistically significant. Overall, Table 3 Panel A indicates that there is an increase in private investment facilitated by the SuperNet. Therefore, on a province-wide basis, the SuperNet increases the value of government expenditures by increasing the level of private investment in the Province.

[Table 3 About Here] 
Table 3 Panel B stands in significant contrast to Table 3 Panel A. Panel B shows that, for communities with less than 10,000 persons, investment levels are lower after the SuperNet in the SuperNet communities; and, this difference is statistically significant for minor projects at the 1 percent level of significance. As in Table 3 Panel A, the differences prior to the SuperNet were not statistically significant. Overall, while the SuperNet has facilitated an increase in private investment across all communities in the province, this increase only occurs among the larger communities. Among the smaller communities, the investment levels have declined in SuperNet communities.

This preliminary look at the data thus suggests that the SuperNet facilitates a transfer of investment (i.e., and therefore economic production) from rural communities to urban communities. One likely explanation is that this transfer is related to scale economies that exist in more urban centers where production is more cost efficient. Residents in rural communities with access to the SuperNet are able to consume items at a lower cost, and local producers in rural communities are less inclined to invest after the introduction of the SuperNet. But again, this is only a preliminary look at the data and summary statistics; more conclusive evidence in a multivariate context is provided in the next section.

Table 4 presents a correlation matrix. The correlations shown are for the entire sample of firms, and are generally consistent with Table 3 Panel A (which likewise considers the full sample). Table 3 also provides guidance for potential collinearity problems that arise with the multivariate analyses in the next section. Our results in the next section have been checked for collinearity biases, among other things. Overall, the reported results are extremely robust, as discussed further below.

[Table 4 About Here] 


\section{Multivariate Analyses}

The econometric analyses in this section use Poisson regressions. Poisson regressions appropriately account for the distribution of the dependent variable: the variable is bounded below at 0 ; the median level of investment is 0 in any given community; and, the right tail of the distribution comprises a small density and is skewed (in the same way as a Poisson distribution). We did consider other distributional assumptions (including a normal distribution, in conjunction with standard OLS methods), and found similar results, albeit with a worse fit of the model to the data. Those alternative specifications are available upon request. Standard diagnostic tests strongly confirmed the use of Poisson regressions.

To explicitly show robustness, and different effects for different subsamples in the data, Table 5 presents a total of 12 different regression models. Model 1 uses the full sample of 801 communities (including the two major cities in the province, because investment is likely to be affected by the SuperNet as firms’ markets expand by having easier access to consumers in rural economies). Model 2 considers all 801 communities, but only minor projects. Model 3 likewise considers all 801 communities, but only major projects. Models 4-9 consider the communities with populations no greater than 50 thousand, 15 thousand, 10 thousand, 5 thousand, one thousand, and five hundred, respectively. As discussed below, the data strongly indicate differences in the effect of the SuperNet on communities of different populations. Model 10 presents regressions for the subsample of all communities that are more than 150 kilometers from Calgary and Edmonton (the maximum population in this range is 66,035 persons). Model 11 and 12 are similar to Model 10 , the difference being that their subsamples are restricted by the populations of the more remote communities to no more than 30,000 persons (Model 11) and 10,000 persons (Model 12) respectively. Additional specifications not explicitly presented are available upon request. 
[Table 5 About Here]

The regression models highlight a number of interesting features about the data regarding the relationship between the award of a SuperNet connection and project investment levels. Models 1-3 clearly show that the non-SuperNet communities experience comparatively lower investment levels than SuperNet communities. On average across all communities and all projects, non-SuperNet communities experience a reduction of investment of approximately Can\$580,000 (Model 1). For the subset of minor projects, non-SuperNet communities experience less investment on the order of Can\$290,000 (Model 2). For the subset of major projects, nonSuperNet communities have, on average, less investment by Can $\$ 3,041,000$ (Model 3). This evidence supports Hypothesis 3, which conjectured that the SuperNet would bring an overall positive benefit in terms of more private investment, even if there were some losses among select SuperNet communities.

The negative relationship between non-SuperNet communities and investment levels continues to hold for the subsample of all communities with populations up to 50,000 residents (Model 4) and 15,000 residents (Model 5). However, importantly, notice that the relationship between non-SuperNet communities and investment is positive and statistically significant for the more restricted subsamples of communities with populations up to 10,000 residents (Model 6), 5,000 residents (Model 7), 1,000 residents (Model 8), and 500 residents (Model 9). For these latter subsamples, the relationship is also economically significant: investment is higher by approximately Can\$200,000 (Model 7) to Can\$441,000 (Model 9) among communities that did not receive the SuperNet. This is evidence supports Hypothesis 1, which conjectured that smaller SuperNet communities would experience a reduction in investment because they lack a preexisting base of real entrepreneurial activity.

It is further important to note that the switch in sign in the relationship between the award of the SuperNet and investment levels occurs for different population levels among the 
communities that are more geographically remote. Models 10-12 restrict the sample to only those communities that are more than 150 kilometers from Calgary and Edmonton. It is instructive to use this cutoff level, because the distance between Calgary and Edmonton is 300 kilometers and, as discussed, virtually all who work in Calgary or Edmonton commute from a distance of less than 150 kilometers. The data indicate that the change in the sign of the relation between investment and the SuperNet occurs around 30,000 residents, so that among cities with more than 30,000 residents, there is a positive relation between the SuperNet and investment (Model 10), but among communities with fewer than 30,000 residents, there is a negative relation between communities that receive the SuperNet and investment (Models 11 and 12). One explanation for this observation -- that the SuperNet has a negative effect on investment among medium-sized communities that are more geographically remote -- is that the more remote communities are not only less cost efficient, but also agglomeration is initiated in the larger remote communities (substitute cities), so investments are increasingly concentrated in them , consistent with Hypothesis 2. That is, a community that is closer to Calgary or Edmonton will have more competitive markets with Calgary and Edmonton's. Only the largest cities (five in total; see the number of observations in Models 10 and 11) that are more than 150 kilometers away from Calgary and Edmonton are not adversely affected in terms of new investment after the introduction of the SuperNet, because broadband Internet does not introduce grossly different levels of competition among those larger communities, and their existing size in effect facilitates agglomeration.

Note that many of the control variables are statistically significant. Population levels tend to be statistically significant, but are not always positively related to investment levels (it depends on the subsamples of communities considered; see, e.g., Models 4 and 5). Note that the sensitivity of this relation is not attributable to collinearity across the included variables (for example, the same relations hold when even all other variables are excluded). There tends to be a 
positive relation between investment and distance from Calgary, but this control variable seems to account for lower investment among satellite communities that are proximate to larger cities.

Prior planned private investment is negatively related to current planned private investment for all subsamples of the communities as well as for the full sample (Models 1-12). Prior planned public investment is negatively related to current planned private investment for communities with more than 10,000 residents (Models 1-5), but positively related for communities with more than 10,000 residents (Models 6-9). Also, prior planned public investment is positively related to current planned private investment for all communities that are more than 150 kilometers from Calgary and Edmonton. (Completed prior public/private partnership investments are excluded as a right-hand-side variable because there were few projects of this kind that were actually completed, and the inclusion of that variable caused estimation problems.) Generally, therefore, the date indicate that public investment expenditures crowd out private investment expenditures in larger cities near Calgary and Edmonton, but facilitate private investment in smaller and more remote communities. The effect of private/public partnership investments is similar to that of pure public investment, although less robust. Completed private prior investment projects are positively related to planned private investment for all communities and subsamples (Model 1-12). Completed prior public investment is negatively related to planned private investment in the full sample (Models 1-3), but positively related in the subsamples in Models 4-9, and negatively related for the remote communities (Models 10-12). Generally, therefore, the data indicate that prior private investment spurs new private investment, while prior public investment does not always spur new private investment and in fact may crowd out new private investment. 


\section{Discussion}

This paper empirically addressed the question of whether government provided broadband Internet will facilitate entrepreneurship in rural communities. To the best of our knowledge, this is the first paper to address this issue. We developed a number of new testable hypotheses based on literature in economics, entrepreneurship, and regional development. We conjectured that the government expenditure on Internet would lead to a decline in entrepreneurship among smaller geographically remote Internet communities, because firms in those communities would face new competitors worldwide and would not have a sufficient preexisting cluster of entrepreneurial activities to effectively compete. Larger remote communities, by contrast, were expected to experience an increase in entrepreneurship. Overall, we also expected Internet communities to experience more entrepreneurship than non-Internet communities.

We used a natural experiment known as the SuperNet - a project introduced by the Government of Alberta in November 2000, at a cost of Can\$193 million, for the provision of state-of-the-art "SuperNet" broadband Internet access to all rural communities within the province that met specific criteria with community institutions. The comprehensive data considered in all communities over 1999-2003 indicated that small remote communities that received the SuperNet experienced a decline in entrepreneurship relative to those communities that did not receive the SuperNet. Larger and more urban SuperNet cities, by contrast, experienced an increase in entrepreneurship after the introduction of the SuperNet. The degree to which entrepreneurship was facilitated by the SuperNet diminished with community size, and the minimum community size that enjoyed greater entrepreneurship increased with the distance away from major cities. Further research could investigate longer-term effects of Internet technology on entrepreneurship in rural communities. 
The notable finding of a comparative reduction in entrepreneurship among remote SuperNet communities is perhaps best explained by a shift in opportunities facilitated by the SuperNet. The SuperNet makes flat the rugged rural world of Alberta, and opens the door to knowledge spillovers and competition from around the world for small businesses in rural communities. It is natural to expect a comparative decline in entrepreneurship in rural communities as production shifts to more cost efficient cities. It was an unexpected finding that more investments are being channeled to the larger communities that are farther from the cities. The data indicate that these communities, with added access to knowledge and social networks, have a potential pursuant to agglomeration to become "substitute cities". Another factor consistent with the data is that the SuperNet, allowing for knowledge spillovers and access to social networks, shifts preferences towards new and different leisure activities that were previously less readily available to rural Albertans.

There are extensions and further research in empirics and theory development that can be based on this study. For instance, one could examine a longer period beyond the 1999-2003 sample used in this paper. Our sample was confined to data availability, with historical records on all investments from all communities hand assembled from government records. While our evidence shows a propensity for agglomeration among larger SuperNet communities because of increased knowledge resources and social network resources, it is unclear whether such agglomeration will evolve into clusters in the distant future -- it is beyond the scope of this paper to determine whether the entrepreneurial orientation of larger communities changes as a result of the implementation of the SuperNet (see e.g. West, Bamford \& Marsden, 2008, which highlights the importance of the intangible resource, entrepreneurial orientation, or culture, in the gestation of entrepreneurial activity). This area of study will be relevant for future research.

An additional area of future research is public spending over time, to determine whether policymakers ensure that their governmental programs are successful and have their desired policy effect. Further research on that topic in the context of the Alberta SuperNet might prove to 
be fruitful. For instance, our analysis does not assume that there are spillovers in entrepreneurship from one community to another community. One interpretation of the data (although probably less compelling) is that there is less entrepreneurship among smaller, more remote SuperNet communities because the benefits of any entrepreneurship are transferable across communities that are linked by the SuperNet (and hence less entrepreneurship is needed in companion communities as entrepreneurship decisions do not need to be duplicated). This issue could be investigated in the future with different data. Also, our data do not enable a welfare analysis of the introduction of the Internet to rural communities. Further work in the spirit of Gabriel, Mattey \& Wascher (2003) on quality-of-life differentials in urban versus rural areas related to the adoption of the Internet could provide a fruitful avenue for further research.

The data introduced in this paper have significant implications for firms and consumers, as well as for formulating government policy towards providing and subsidizing broadband Internet for rural communities. On the one hand, the data suggest that a side effect of such policies may be the potential creation of entrepreneurial or technological clusters that can only benefit rural economic development. On the other hand, the data indicate that, in the short term, smaller communities may suffer as a result of the agglomeration that results in other larger, potentially substitute cities (and potential clustering may result from such agglomeration) at the cost of their own economies. Policy makers will have to take into account this more unpleasant side effect of their policies in determining the need for other resources to be sent to smaller communities to cope with this prospect. Policy makers also will have to ensure that the larger communities have the necessary resources to take full advantage of the impending agglomeration, to prepare themselves and their production resources to make the leap from agglomeration to facilitate clustering, and to enable such substitute cities to be formed more efficiently and effectively. While this study can only suggest the potential for beneficial changes to be made in rural production efforts as a result of introducing advanced technology within a region, it is up to policy makers to take such suggestions and make them a reality. Future research could explore 
these and related questions in further detail with other government policies in different regions around the world.

The paper's key finding is that virtual entrepreneurial clusters are not independent of real entrepreneurial clusters. This finding is important for agglomeration theory as it strengthens arguments related to the importance of physical localisation (Audtresch \& Feldman, 1996a,b; Audretsch \& Keilbach, 2007, 2008). It also highlights the importance of an interaction between agglomeration and spill over theory as communication and knowledge dispersion is dependent not only on Internet access but also on an interaction with real clusters (Agarwal, Audretsch \& Sarkar, 2007). In turn, this finding has implications for path dependency and evolutionary theory (Aldrich, 1990) and the long-term development of entrepreneurship activities in Internet versus non-Internet communities. These long-term issues could be explored in further theoretical and empirical work.

Policy makers intending to create clusters of entrepreneurial activity should strengthen broadband Internet access for rural areas of sufficient size for a real cluster to develop. Our dataset indicated that smaller more remote communities experienced a decline in entrepreneurship upon receiving SuperNet access. Firms in smaller, more remote communities will face increased competition when consumers have Internet access, and without a pre-existing cluster of entrepreneurial activity, these firms may not be able to compete. Further research could identify conditions that would help an Internet-based rural community to develop greater entrepreneurial proclivity.

\section{REFERENCES}

Acs, Z.J., \& Audretsch, D. (1987). Innovation, market structure, and firm size, Review of Economics and Statistics, 69, 567-575.

Agarwal, R., Audretsch, D., \& Sarkar, M. (2007). The process of creative construction: knowledge spillovers, entrepreneurship and economic growth. Strategic Entrepreneurship Journal, 1, 263 - 286 
Aldrich, H.E. (1990). Using an ecological perspective to study organizational founding rates. Entrepreneurship Theory and Practice, 14, 7-24.

Anas, A., \& Xiong, K. (2003). Intercity trade and the industrial diversification of cities. Journal of Urban Economics, 54, 258-276.

Audretsch, D. (2007a). Entrepreneurship Capital and Economic Growth. Oxford Review of Economic Policy, 23, 63-78.

Audretsch, D. (2007b). The Entrepreneurial Society, Oxford: Oxford University Press.

Audretsch, D. B., \& Dohse, D. (2007). Location: A neglected determinant of firm growth. Review of World Economics, 143, 79-107.

Audtresch D.B., \& Feldman, M.P. (1996a). R\&D Spillovers and the Geography of Innovation and Production. American Economic Review, 86, 630-640

Audtresch D.B., \& Feldman, M.P. (1996b). Innovative Clusters and the Industry Life Cycle. Review of Industrial Organization, 11, 253-273

Audretsch, D., \& Keilbach, M. (2007). The localisation of entrepreneurship capital: evidence from Germany. Regional Science, 86, 351-365.

Audretsch, D., \& Keilbach, M. (2008). The knowledge spillover theory of entrepreneurship and economic growth. Working Paper, Max Plank Institute of Economics.

Audretsch, D., Keilbach, M., \& Lehmann, E. (2006). Entrepreneurship and economic growth. Oxford University Press, 2006.

Braunerhjelm, P \& Borgman, B. (2006). Agglomeration, diversity and regional growth: The effects of poly-industrial versus mono-industrial agglomerations. Working Paper No 71.

Brown, J.R., \& Goolsbee, A. (2002). Does the Internet make markets more competitive? Evidence from the life insurance industry. Journal of Political Economy, 110, 481-507.

Castells, M. (2001). The Internet galaxy: reflections on the Internet, business and society. Oxford: Oxford University Press.

Chandler, Jr., A.D. (2006). How high technology industries transformed work and life worldwide from the 1880s to the 1990s. Capitalism and Society, 1(2), Article 1.

Chinn, M.D., \& Fairlie, R.W. (2004). The determinants of the global divide: a cross-country analysis of computer and Internet penetration. NBER Working Paper 10686.

Couclelis, H. (2004). Pizza over the Internet: e-commerce, the fragmentation of activity and the tyranny of the region, Entrepreneurship \& Regional Development, 16, 41-54.

Cressy, R. (2002). Funding gaps: a symposium, Economic Journal, 112, F1-F16. 
Davidsson, P. \& Wiklund, J. (2001). Levels of analysis in entrepreneurship research: Current research practice and suggestions for the future. Entrepreneurship Theory and Practice, 25, 81-99.

Devereux, M. P., Griffith R. \& Simpson, H. (2004). The geographic distribution of production activity in the UK. Regional Science and Urban Economics, 34, 533-564.

Feldman, M. P. (2001). The Entrepreneurial Event Revisited: An Examination of New Firm Formation in the Regional Context. Industrial and Corporate Change, 10, 861-891.

Feldman, M.P. (2002). The Internet Revolution and the Geography of Innovation, International Social Science Journal, 54, 47-56.

Feldman, M.P., \& Audretsch, D.B. (1999). Innovation in cities: Science-based diversity, specialization and localized competition, European Economic Review, 43, 409-429.

Friedman, T.L. (2005). The world is flat: a brief history of the twenty-first century. New York: Farrar, Straus and Giroux.

Forman, C., Goldfarb A., \& Greenstein, S. (2002). Digital dispersion: an industrial and geographic census of commercial Internet use. NBER Working Paper W9287.

Forman, C., Goldfarb A., \& Greenstein, S. (2005). How did location affect adoption of the commercial Internet? Global village vs. urban leadership. Journal of Urban Economics, 58, 389-420.

Forman, C., Goldfarb, A., \& Greenstein, S. (2006). Understanding the inputs into innovation: Do cities substitute for internal firm resources? Working Paper, Carnegie Melon University.

Fujita, M. \& Thisse, J.F. (2002). Economics of agglomeration: cities, industrial location and regional growth, Cambridge: Cambridge University Press.

Furman, J.L., Kyle, M.K., Cockburn, I., \& Henderson, R.M. (2008). Public and private spillovers, location and the productivity of pharmaceutical research. Annales d'Economie et de Statistique, forthcoming

Gabriel, S.A., Mattey J.P., \& Wascher, W.L. (2003). Compensating differentials and evolution in the quality-of-life among U.S. states. Regional Science and Urban Economics, 33, 619649.

Goolsbee, A., \& Guryan, J. (2005). The impact of Internet subsidies in public schools. Review of Economics and Statistics, 88, 336-347.

Gordon, R.J., (2000). Does the "New Economy" measure up to the great inventions of the past? Journal of Economic Perspectives 14, 49-74.

Haltiwanger, J., Jarmin, R., \& Schank, T. (2003). Productivity, investment in ICT and market experimentation: micro evidence from Germany and the U.S., Working Paper, University of Maryland.

Hotelling, H., (1929). Stability in Competition. Economic Journal, 39, 41-57. 
Krugman, P., (1991). Geography and Trade. Cambridge, Mass.: MIT Press.

Litan, R.E., \& Rivlin, A.M. (2001). The Economy and the Internet: What Lies Ahead? In Litan, R.E and A.M. Rivlin eds. The Economic Payoff from the Internet Revolution, pp. 1-28. Washington, DC: Brookings Institution Press.

Malecki, E.J. (2004). Fibre tracks: explaining investment in fibre optic backbones, Entrepreneurship \& Regional Development, 16, 21-39.

Marshall, A. (1890). Principles of economics. London. Macmillen.

Mason, C.M., \& Harrison, R.T. (2002). The geography of venture capital investment in the UK. Transactions of the Institute of British Geographers, 27, 427-451.

Naudé, W., Gries, T., Wood, E., \& Meintjies, A. (2008). Regional determinants of entrepreneurial start-ups in a developing country, Entrepreneurship \& Regional Development, 20, 111-124.

OECD (1996). Government programmes for venture capital. Paris: Organization for Economic Corporation and Development.

OECD (1998). Fostering entrepreneurship. Paris, Organisation for Economic Cooperation and Development.

Prieger, J.E. (2003). The supply side of the digital divide: Is there equal availability in the broadband Internet access market? Economic Inquiry, 41, 346-364.

Reynolds, P.D., Storey, D.J., \& Westhead, P. (1994). Cross-national comparisons of the variation in new firm formation rates. Regional Studies, 28, 443-456

Sinai, T., \& Waldfogel, J. (2004). Geography and the Internet: is the Internet a substitute for cities? Journal of Urban Economics, 56, 1-24.

Smithies, A.F. (1941). Optimum Location in Spatial Competition. Journal of Political Economy, 49, 423-39.

Steinle, C. \& Schiele, H. (2002). When do industries cluster? A proposal on how assess an industry's propensity to concentrate at a single region or nation. Research Policy, 31, 849-858.

Tan, J. (2006). Growth of industry clusters and innovation: lessons from Beijing Zhongguancun Science Park. Journal of Business Venturing, 26, 827-850.

Van Geenhuizen, M. (2008). Knowledge networks of young innovators in the urban economy: biotechnology as a case study, Entrepreneurship \& Regional Development, 20, 161-183.

Varian, H.R. (2002). The demand for bandwith: evidence from the INDEX project. In Crandall, R.W., \& Alleman, J.H., Eds. Broadband: Should We Regulate High-Speed Internet Access? Aei-Brookings Joint Center for Regulatory Studies, American Enterprise Institute. 
Venkataraman, S. (2004). Regional transformation through technological entrepreneurship. Journal of Business Venturing, 19, 153-167.

West, G.P., Bamford, C.E., \& Marsden, J.W. (2008). Contrasting entrepreneurial economic development in emerging Latin American economies: Applications and extensions of resource-based theory, Entrepreneurship Theory and Practice, 32, 15-36.

\section{Internet Resources}

Alberta. Department of Economic Development. Policy and Economic Analysis Division, and Tourism and Industry Division. Inventory of major Alberta projects. By Kathy Dumaresq. http://www.alberta-canada.com/statpub/mpindex.cfm

Alberta. Department of Economic Development. Policy and Analysis Division. and Tourism and Industry Division. Inventory of Alberta regional projects. http://www.albertacanada.com/statpub/rpindex.cfm

Alberta Department of Municipal Affairs. Municipal Services. Municipal Statistics. http://lwww3.gov.ab.calmalms/mfistable/mfisripfiles.cfm

Alberta Department of Municipal Affairs. Municipal Services Branch. Official Population List http://www3.gov.ab.ca/ma/ms/official_pop_lists.cfm

Alberta Economic Development. Inventory of major Alberta projects. Edmonton, AR: Alberta Economic Development, Policy and Economic Analysis Division and Tourism and Industry Division, 1998-2003. http://www.alberta-canada.com/statpub/mpindex.cfm

Alberta Economic Development. Inventory of Alberta regional projects. Edmonton, AB: Alberta Economic Development, Policy and Economic Analysis Division and Tourism and Industry Division. 1999-2003. Quarterly publication. Continues Minor development projects. http://www.alberta-canada.com/statpub/mpindex.cfm

Alberta Economic Development. Monthly Economic Review. Edmonton. AB: Alberta Economic Development, Strategic Resources Division. http://www.albertacanada.com/statpub/economicHighlights/economicReviews.cfm

Alberta SuperNet Map. http://www.albertasupernet.ca/

Commuting Statistics http://www.pembina.org/pdf/publications/22.Commuting.pdf

Ministry of Aboriginal Affairs and Northern Development. Intergovernmental and Aboriginal Affairs. First Nations of Alberta - Indian Register Population. http://www.aand.gov.ab.ca/AAND.asp?lid=133 


\section{Table 1. Definitions of Variables}

This table defines the variables used in the empirical analyses. Variables are recorded for 801 distinct Albertan communities as identified by the Albertan Department of Municipal Affairs, and Alberta Economic Development.

\begin{tabular}{|c|c|c|}
\hline $\begin{array}{l}\text { Variable } \\
\text { Identifier }\end{array}$ & Source & Definition \\
\hline \multicolumn{3}{|l|}{$\frac{\text { Investment }}{\text { Variables }}$} \\
\hline $\begin{array}{l}\text { Minor } \\
\text { Projects } \\
\text { After } \\
\text { SuperNet }\end{array}$ & $\begin{array}{l}\text { Alberta Economic } \\
\text { Development. Inventory of } \\
\text { Alberta regional projects. } \\
\text { Edmonton, AB: Alberta } \\
\text { Economic Development, Policy } \\
\text { and Economic Analysis }\end{array}$ & $\begin{array}{l}\text { A planned investment announced in 2001, } 2002 \text { or } 2003 \text {. Private investment expenditures only. } \\
\text { "Minor" refers to investments that are less than } \$ 2 \text { million per year, as classified by Alberta } \\
\text { Economic Development (total amounts may exceed } \$ 2 \text { million for minor projects planned over } \\
\text { more than } 1 \text { year). Investment expenditures are identified for particular communities, and do } \\
\text { not include province-wide investment expenditures (such as the SuperNet). A "Project" refers } \\
\text { to a construction project. }\end{array}$ \\
\hline $\begin{array}{l}\text { Major } \\
\text { Projects } \\
\text { After } \\
\text { SuperNet }\end{array}$ & $\begin{array}{l}\text { Division and Tourism and } \\
\text { Industry Division. 1999-2003. } \\
\text { Quarterly publication. } \\
\text { Continues Minor development } \\
\text { projects. Current issue is } \\
\text { available on the department } \\
\text { website: }\end{array}$ & $\begin{array}{c}\text { A planned investment announced in 2001, } 2002 \text { or } 2003 \text {. Private investment expenditures only. } \\
\text { "Major" refers to investments that are greater than } \$ 2 \text { million per year, although that amount } \\
\text { might be less for a community where the investment is spread across more than } 1 \text { community. } \\
\text { Investment expenditures are identified for particular communities, and do not include province- } \\
\text { wide investment expenditures (such as the SuperNet). A “Project" refers to a construction } \\
\text { project. }\end{array}$ \\
\hline $\begin{array}{l}\text { Total } \\
\text { Projects } \\
\text { After } \\
\text { SuperNet }\end{array}$ & $\begin{array}{l}\underline{\text { http://www.alberta- }} \\
\text { canada.com/statpub/albertaCon } \\
\underline{\text { structionProjects/mpindex.cfm }}\end{array}$ & $\begin{array}{l}\text { The sum of Minor Projects After SuperNet and Major Projects After SuperNet. A "Project” } \\
\text { refers to a construction project. }\end{array}$ \\
\hline \multicolumn{3}{|l|}{$\frac{\text { Demographi }}{\text { c Variables }}$} \\
\hline $\begin{array}{l}\text { Non- } \\
\text { SuperNet }\end{array}$ & $\begin{array}{c}\text { Alberta SuperNet. Previous } \\
\text { Rollout schedule, 1998-2001. } \\
\text { http://www.albertasunernet.ca/ }\end{array}$ & $\begin{array}{l}\text { A community that will not receive SuperNet access. The SuperNet is a Can } \$ 193 \text { million } \\
\text { government expenditure providing the fastest Internet technology anywhere for the given } \\
\text { technology of the period. The project and SuperNet communities were announced in }\end{array}$ \\
\hline Community & $\frac{\text { Prociress/rollout+schedule/new }}{\text { completiontotal.pdf }}$ & $\begin{array}{l}\text { November 2000. Communities to receive the SuperNet included any community that had a } \\
\text { hospital or a public school. }\end{array}$ \\
\hline Population & $\begin{array}{l}\text { Alberta. Department of } \\
\text { Municipal Affairs. Municipal } \\
\text { Services Branch. Official } \\
\text { Population List, } 1960-2002 . \\
\text { http://www3.gov.ab.ca/ma/ms/ } \\
\underline{\text { official_pop_lists.cfm }}\end{array}$ & $\begin{array}{l}\text { The population in the community, as at } 2001 \text { (populations at other years for each of the } \\
\text { communities was extremely similar and had no bearing on the results). }\end{array}$ \\
\hline $\begin{array}{l}\text { Distance } \\
\text { from Calgary }\end{array}$ & Microsoft Expedia TripPlanner & $\begin{array}{l}\text { The traveling distance by car in kilometers from the community to Calgary, the economic and } \\
\text { financial capital of the province. }\end{array}$ \\
\hline $\begin{array}{l}\text { Distance } \\
\text { from } \\
\text { Edmonton }\end{array}$ & $\begin{array}{l}\text { ã1988-1997 by Microsoft } \\
\text { Corporation. }\end{array}$ & $\begin{array}{l}\text { The traveling distance by car in kilometers from the community to Edmonton, the } \\
\text { governmental capital of the province. }\end{array}$ \\
\hline
\end{tabular}


Table 1. (Continued)

\begin{tabular}{|c|c|c|}
\hline \multicolumn{3}{|r|}{ Table 1. (Continued) } \\
\hline $\begin{array}{l}\text { Variable } \\
\text { Identifier }\end{array}$ & Source & Definition \\
\hline $\begin{array}{c}\underline{\text { Prior }} \\
\underline{\text { Investment }} \\
\text { Variables }\end{array}$ & & \\
\hline $\begin{array}{l}\text { Prior } \\
\text { Planned } \\
\text { Private } \\
\text { Investment }\end{array}$ & & $\begin{array}{l}\text { A planned investment announced in } 1999 \text { or } 2000 \text {. Private investment expenditures only. } \\
\text { Includes both "Minor" and "Major" investments in the community, as defined above. } \\
\text { Investment expenditures are identified for particular communities, and do not include province- } \\
\text { wide investment expenditures (such as the SuperNet). }\end{array}$ \\
\hline $\begin{array}{l}\text { Prior } \\
\text { Planned } \\
\text { Public } \\
\text { Investment }\end{array}$ & & $\begin{array}{l}\text { A planned investment announced in } 1999 \text { or 2000. Public (governmental) investment } \\
\text { expenditures only. Includes both "Minor" and "Major" investments in the community, as } \\
\text { defined above. Investment expenditures are identified for particular communities, and do not } \\
\text { include province-wide investment expenditures (such as the SuperNet). }\end{array}$ \\
\hline $\begin{array}{l}\text { Prior } \\
\text { Planned } \\
\text { Private/Publi } \\
\text { c Investment }\end{array}$ & $\begin{array}{l}\text { Alberta Economic } \\
\text { Development. Inventory of } \\
\text { Alberta regional projects. } \\
\text { Edmonton, AB: Alberta }\end{array}$ & $\begin{array}{l}\text { A planned investment announced in } 1999 \text { or } 2000 \text {. Public (governmental) / private partner } \\
\text { investment expenditures only. Includes both "Minor" and "Major" investments in the } \\
\text { community, as defined above. Investment expenditures are identified for particular } \\
\text { communities, and do not include province-wide investment expenditures (such as the } \\
\text { SuperNet). }\end{array}$ \\
\hline $\begin{array}{l}\text { Completed } \\
\text { Actual } \\
\text { Private } \\
\text { Investment }\end{array}$ & $\begin{array}{l}\text { Economic Development, Policy } \\
\text { and Economic Analysis } \\
\text { Division and Tourism and } \\
\text { Industry Division. 1999-2003. } \\
\text { Quarterly publication. } \\
\text { Continues Minor development }\end{array}$ & $\begin{array}{c}\text { Completed investment project in } 1999 \text { or } 2000 \text {. Private investment expenditures only. Includes } \\
\text { both "Minor" and "Major" investments in the community, as defined above. Investment } \\
\text { expenditures are identified for particular communities, and do not include province-wide } \\
\text { investment expenditures (such as the SuperNet). }\end{array}$ \\
\hline $\begin{array}{l}\text { Completed } \\
\text { Actual } \\
\text { Public } \\
\text { Investment }\end{array}$ & $\begin{array}{l}\text { projects. Current issue is } \\
\text { available on the department } \\
\text { website } \\
<\underline{\text { http://www.alberta- }} \\
\frac{\text { canada.com/statpub/mpindex.cf }}{\mathrm{m}>\text {. }}\end{array}$ & $\begin{array}{l}\text { Completed investment project in } 1999 \text { or } 2000 \text {. Public (governmental) investment expenditures } \\
\text { only. Includes both "Minor" and "Major" investments in the community, as defined above. } \\
\text { Investment expenditures are identified for particular communities, and do not include province- } \\
\text { wide investment expenditures (such as the SuperNet). }\end{array}$ \\
\hline $\begin{array}{l}\text { Completed } \\
\text { Actual } \\
\text { Private/Publi } \\
\text { c Investment }\end{array}$ & & $\begin{array}{l}\text { Completed investment project in } 1999 \text { or 2000. Public (governmental) / private partner } \\
\text { investment expenditures only. Includes both "Minor" and "Major" investments in the } \\
\text { community, as defined above. Investment expenditures are identified for particular } \\
\text { communities, and do not include province-wide investment expenditures (such as the } \\
\text { SuperNet). }\end{array}$ \\
\hline $\begin{array}{l}\text { Industry } \\
\text { Variables }\end{array}$ & & \\
\hline $\begin{array}{l}\text { Industry } \\
\text { Dummy } \\
\text { Variables }\end{array}$ & & $\begin{array}{l}\text { Dummy variables equal to one for industries in which the announced investments took place } \\
\text { after the announcement of the SuperNet. Industry dummy variables are included for the } \\
\text { following industries: agriculture, chemicals and petrochemicals, commercial/retail, } \\
\text { commercial/retail/residential, forestry, infrastructure, institutional, manufacturing, mining, oil / } \\
\text { gas and oil sands, other industrial, pipelines, power, residential, telecommunications, tourism } \\
\text { and recreation. }\end{array}$ \\
\hline
\end{tabular}


Table 2. Summary Statistics

This table presents the mean, median, standard deviation, minimum and maximum for the variables defined in Table 1 and used in the empirical analyses. Note that project investment amounts for all variables are expressed in millions of 2003 Canadian dollars.

\begin{tabular}{|c|c|c|c|c|c|c|}
\hline Variable Identifier & Mean & Median & $\begin{array}{l}\text { Standard } \\
\text { Deviation }\end{array}$ & Minimum & Maximum & $\begin{array}{l}\text { Number of } \\
\text { Observations }\end{array}$ \\
\hline \multicolumn{7}{|l|}{$\frac{\text { Announced Investment }}{\text { Variables }}$} \\
\hline $\begin{array}{l}\text { Minor Projects After } \\
\text { SuperNet }\end{array}$ & 0.30 & 0.00 & 1.71 & 0.00 & 38.30 & 801 \\
\hline $\begin{array}{l}\text { Major Projects After } \\
\text { SuperNet }\end{array}$ & 10.15 & 0.00 & 87.85 & 0.00 & 1764.70 & 801 \\
\hline Total Projects After SuperNet & 10.45 & 0.00 & 88.12 & 0.00 & 1764.70 & 801 \\
\hline \multicolumn{7}{|l|}{ Demographic Variables } \\
\hline Non-SuperNet Community & 0.49 & 0.00 & 0.50 & 0.00 & 1.00 & 801 \\
\hline Population & 3628.12 & 177.00 & 36574.35 & 1.00 & 819334.00 & 801 \\
\hline Distance from Calgary (Km) & 363.68 & 328.00 & 233.14 & 0.00 & 1825.80 & 801 \\
\hline $\begin{array}{l}\text { Distance from Edmonton } \\
\qquad(\mathrm{Km})\end{array}$ & 274.39 & 243.00 & 185.43 & 0.00 & 1539.10 & 801 \\
\hline \multicolumn{7}{|l|}{$\underline{\text { Prior Investment Variables }}$} \\
\hline $\begin{array}{l}\text { Prior Planned Private } \\
\text { Investment }\end{array}$ & 20.29 & 0.00 & 190.93 & 0.00 & 4483.11 & 801 \\
\hline $\begin{array}{l}\text { Prior Planned Public } \\
\text { Investment }\end{array}$ & 2.08 & 0.00 & 23.88 & 0.00 & 644.10 & 801 \\
\hline $\begin{array}{c}\text { Prior Planned Private/Public } \\
\text { Investment }\end{array}$ & 0.07 & 0.00 & 1.03 & 0.00 & 25.00 & 801 \\
\hline $\begin{array}{l}\text { Completed Actual Private } \\
\text { Investment }\end{array}$ & 12.95 & 0.00 & 128.17 & 0.00 & 2984.10 & 801 \\
\hline $\begin{array}{c}\text { Completed Actual Public } \\
\text { Investment }\end{array}$ & 1.87 & 0.00 & 15.88 & 0.00 & 319.00 & 801 \\
\hline $\begin{array}{c}\text { Completed Actual } \\
\text { Private/Public Investment }\end{array}$ & 0.09 & 0.00 & 2.47 & 0.00 & 70.00 & 801 \\
\hline
\end{tabular}




\section{Table 3. Comparison Tests}

This table presents comparison of means and medians tests for the variables defined in Table 1 for communities that will and will not receive the Alberta SuperNet. Note that project investment amounts for all variables are expressed in millions of 2003 Canadian dollars. '---': P-value was insignificant for the difference of medians test. *, **, *** Significant at the $10 \%, 5 \%$ and $1 \%$ levels, respectively.

\section{Panel A. Full Sample of All Communities}

\begin{tabular}{|c|c|c|c|c|c|c|c|c|}
\hline \multirow{2}{*}{ Variable Identifier } & \multicolumn{3}{|c|}{ SuperNet Communities } & \multicolumn{3}{|c|}{ Non SuperNet Communities } & \multirow{2}{*}{$\begin{array}{l}\text { Difference } \\
\text { of Means } \\
\text { Test }\end{array}$} & \multirow{2}{*}{$\begin{array}{l}\text { Difference } \\
\text { of } \\
\text { Medians } \\
\text { Test }\end{array}$} \\
\hline & $\begin{array}{l}\text { Number of } \\
\text { Communities }\end{array}$ & Mean & Median & $\begin{array}{l}\text { Number of } \\
\text { Communities }\end{array}$ & Mean & Median & & \\
\hline \multicolumn{9}{|l|}{ Announced Investment Variables } \\
\hline Minor Projects After SuperNet & 411 & 0.48 & 0.00 & 390 & 0.12 & 0.00 & $3.14 * * *$ & --- \\
\hline Major Projects After SuperNet & 411 & 15.89 & 0.00 & 390 & 4.10 & 0.00 & $1.95^{*}$ & --- \\
\hline $\begin{array}{c}\text { Total Projects After SuperNet } \\
\text { Demographic Variables }\end{array}$ & 411 & 16.37 & 0.00 & 390 & 4.21 & 0.00 & $2.00 * *$ & --- \\
\hline Population & 411 & 5584.53 & 228.00 & 390 & 1566.37 & 130.00 & 1.60 & $\begin{array}{c}\mathrm{p}<= \\
0.0122 * *\end{array}$ \\
\hline Distance from Calgary & 411 & 381.01 & 337.00 & 390 & 345.41 & 315.90 & $2.17 * *$ & $\begin{array}{c}\mathrm{p}<= \\
0.169\end{array}$ \\
\hline $\begin{array}{l}\text { Distance from Edmonton } \\
\text { Prior Investment Variables }\end{array}$ & 411 & 289.15 & 260.00 & 390 & 258.83 & 220.00 & $2.32 * *$ & $\begin{array}{c}\mathrm{p}<= \\
0.0616^{*}\end{array}$ \\
\hline Prior Planned Private Investment & 411 & 29.56 & 0.00 & 390 & 10.52 & 0.00 & 1.45 & --- \\
\hline Prior Planned Public Investment & 411 & 2.93 & 0.00 & 390 & 1.18 & 0.00 & 1.06 & --- \\
\hline $\begin{array}{c}\text { Prior Planned Private/Public } \\
\text { Investment }\end{array}$ & 411 & 0.07 & 0.00 & 390 & 0.07 & 0.00 & -0.09 & --- \\
\hline Completed Actual Private Investment & 411 & 14.18 & 0.00 & 390 & 11.66 & 0.00 & 0.28 & --- \\
\hline Completed Actual Public Investment & 411 & 2.84 & 0.00 & 390 & 0.85 & 0.00 & $1.81^{*}$ & --- \\
\hline $\begin{array}{c}\text { Completed Actual Private/Public } \\
\text { Investment } \\
\end{array}$ & 411 & 0.17 & 0.00 & 390 & 0.00 & 0.00 & 1.01 & --- \\
\hline \multicolumn{9}{|c|}{ Panel B. Communities of fewer than 10,000 residents } \\
\hline \multirow[b]{2}{*}{ Variable Identifier } & \multicolumn{3}{|c|}{ SuperNet Communities } & \multicolumn{3}{|c|}{ Non-SuperNet Communities } & \multirow{2}{*}{$\begin{array}{l}\text { Difference } \\
\text { of Means } \\
\text { Test }\end{array}$} & \multirow{2}{*}{$\begin{array}{c}\text { Difference } \\
\text { of } \\
\text { Medians } \\
\text { Test } \\
\end{array}$} \\
\hline & $\begin{array}{c}\text { Number of } \\
\text { Communities } \\
\end{array}$ & Mean & Median & $\begin{array}{c}\text { Number of } \\
\text { Communities } \\
\end{array}$ & Mean & Median & & \\
\hline \multicolumn{9}{|l|}{ Announced Investment Variables } \\
\hline Minor Projects After SuperNet & 380 & 0.10 & 0.00 & 389 & 0.30 & 0.00 & $-3.31^{* * *}$ & --- \\
\hline Major Projects After SuperNet & 380 & 3.63 & 0.00 & 389 & 5.93 & 0.00 & -0.86 & --- \\
\hline $\begin{array}{c}\text { Total Projects After SuperNet } \\
\text { Demographic Variables }\end{array}$ & 380 & 3.73 & 0.00 & 389 & 6.23 & 0.00 & -0.93 & -- \\
\hline Population & 380 & 1136.70 & 119.00 & 389 & 822.11 & 198.00 & $2.36 * *$ & $\begin{array}{c}\mathrm{p}<= \\
0.0105^{* *}\end{array}$ \\
\hline Distance from Calgary & 380 & 350.60 & 322.00 & 389 & 383.98 & 341.00 & $-1.98^{* *}$ & $\begin{array}{c}\mathrm{p}<= \\
0.183\end{array}$ \\
\hline $\begin{array}{l}\text { Distance from Edmonton } \\
\text { Prior Investment Variables }\end{array}$ & 380 & 262.13 & 220.00 & 389 & 294.47 & 265.00 & $-2.43^{* *}$ & $\begin{array}{c}\mathrm{p}<= \\
0.0661^{*}\end{array}$ \\
\hline Prior Planned Private Investment & 380 & 10.67 & 0.00 & 389 & 6.89 & 0.00 & 1.07 & --- \\
\hline Prior Planned Public Investment & 380 & 1.16 & 0.00 & 389 & 0.65 & 0.00 & 1.10 & --- \\
\hline $\begin{array}{c}\text { Prior Planned Private/Public } \\
\text { Investment }\end{array}$ & 380 & 0.01 & 0.00 & 389 & 0.01 & 0.00 & 0.61 & --- \\
\hline Completed Actual Private Investment & 380 & 11.54 & 0.00 & 389 & 4.52 & 0.00 & 0.87 & --- \\
\hline Completed Actual Public Investment & 380 & 0.84 & 0.00 & 389 & 0.80 & 0.00 & 0.12 & --- \\
\hline $\begin{array}{c}\text { Completed Actual Private/Public } \\
\text { Investment }\end{array}$ & 380 & 0.00 & 0.00 & 389 & 0.00 & 0.00 & 1.00 & --- \\
\hline
\end{tabular}


Table 4. Correlation Matrix

This table presents correlation coefficients for the variables defined in Table 1 . Correlations significant at the 5\% level are highlighted in underline font.

\begin{tabular}{|c|c|c|c|c|c|c|c|c|c|c|c|c|c|}
\hline & & (1) & (2) & (3) & (4) & (5) & (6) & (7) & (8) & (9) & (10) & (11) & (12) \\
\hline & $\underline{\text { Announced Investment Variables }}$ & & & & & & & & & & & & \\
\hline (1) & Minor Projects After SuperNet & 1.00 & & & & & & & & & & & \\
\hline (2) & Major Projects After SuperNet & $\underline{0.15}$ & 1.00 & & & & & & & & & & \\
\hline (3) & Total Projects After SuperNet & $\underline{0.17}$ & $\underline{1.00}$ & 1.00 & & & & & & & & & \\
\hline & Demographic Variables & & & & & & & & & & & & \\
\hline (4) & Non-SuperNet Community & $\underline{-0.11}$ & -0.07 & -0.07 & 1.00 & & & & & & & & \\
\hline (5) & Population & 0.03 & $\underline{0.62}$ & $\underline{0.62}$ & -0.05 & 1.00 & & & & & & & \\
\hline (6) & Distance from Calgary & -0.01 & $\underline{0.09}$ & $\underline{0.09}$ & -0.08 & -0.06 & 1.00 & & & & & & \\
\hline (7) & Distance from Edmonton & -0.01 & $\underline{0.09}$ & $\underline{0.09}$ & -0.08 & -0.04 & $\underline{0.46}$ & 1.00 & & & & & \\
\hline & $\underline{\text { Prior Investment Variables }}$ & & & & & & & & & & & & \\
\hline$(8)$ & Prior Planned Private Investment & $\underline{0.11}$ & $\underline{0.73}$ & $\underline{0.73}$ & -0.05 & $\underline{0.43}$ & 0.03 & -0.01 & 1.00 & & & & \\
\hline (9) & Prior Planned Public Investment & 0.05 & $\underline{0.72}$ & $\underline{0.71}$ & -0.04 & $\underline{0.81}$ & -0.06 & -0.01 & $\underline{0.45}$ & 1.00 & & & \\
\hline (10) & Prior Planned Private/Public Investment & $\underline{0.09}$ & $\underline{0.15}$ & $\underline{0.16}$ & 0.00 & $\underline{0.38}$ & -0.06 & -0.03 & $\underline{0.17}$ & $\underline{0.20}$ & 1.00 & & \\
\hline (11) & Completed Actual Private Investment & 0.07 & $\underline{0.45}$ & $\underline{0.45}$ & -0.01 & $\underline{0.36}$ & -0.02 & -0.01 & $\underline{0.48}$ & $\underline{0.32}$ & $\underline{0.16}$ & 1.00 & \\
\hline (12) & Completed Actual Public Investment & 0.05 & $\underline{0.56}$ & $\underline{0.56}$ & -0.06 & $\underline{0.95}$ & -0.05 & -0.02 & $\underline{0.39}$ & $\underline{0.75}$ & $\underline{0.38}$ & $\underline{0.35}$ & 1.00 \\
\hline (13) & $\begin{array}{c}\text { Completed Actual Private/Public } \\
\text { Investment }\end{array}$ & 0.00 & $\underline{0.71}$ & $\underline{0.70}$ & -0.03 & $\underline{0.79}$ & -0.06 & 0.00 & $\underline{0.40}$ & $\underline{0.95}$ & $\underline{0.14}$ & $\underline{0.30}$ & $\underline{0.71}$ \\
\hline
\end{tabular}


Table 5. Poisson Regression Analyses of Private Investment Expenditures

This table presents regression analyses of total private investment expenditures in each of the SuperNet and Non-SuperNet communities. The variables are as defined in Table 1. Twelve (12) different models are presented to illustrate the robustness of the results to different specifications. Panel A presents three different models for all projects and major (typically <Can\$2million) versus 'minor' (typically >Can\$ 2million) projects (see Table 1 for definitions. Panel B presents estimates for subsamples of the data based on community population. Panel C presents estimates for subsamples of the population based on community population and distance from the major economic centers in the province. White's (1980) heteroskedasticity consistent covariance matrix estimator is used in each specification. *, **, *** Significant at the $10 \%, 5 \%$ and $1 \%$ levels, respectively.

\begin{tabular}{|c|c|c|c|c|c|c|}
\hline \multicolumn{7}{|c|}{ Panel A. Full Sample of All Communities and Subsamples of 'Major' and 'Minor' Projects } \\
\hline & \multicolumn{2}{|c|}{$\begin{array}{l}\text { Model } 1 \\
\text { Full Sample of All Communities } \\
\text { and All Projects }\end{array}$} & \multicolumn{2}{|c|}{$\begin{array}{l}\text { Model } 2 \\
\text { All Communities, Minor } \\
\text { Projects Only }\end{array}$} & \multicolumn{2}{|c|}{$\begin{array}{c}\text { Model } 3 \\
\text { All Communities, Major } \\
\text { Projects Only }\end{array}$} \\
\hline & Coefficient & Marginal Effect & Coefficient & Marginal Effect & Coefficient & Marginal Effect \\
\hline $\begin{array}{c}\text { Constant } \\
\text { Demographic Variables }\end{array}$ & $-1.257 * * *$ & -7.075 & $-2.610 * * *$ & -0.828 & $-1.539 * * *$ & -8.354 \\
\hline Non-SuperNet Community & $-0.582 * * *$ & -3.275 & $-0.916 * * *$ & -0.290 & $-0.560 * * *$ & -3.041 \\
\hline Population & $-1.551 \mathrm{E}-05^{* * *}$ & $-8.732 \mathrm{E}-05$ & $-2.091 \mathrm{E}-06$ & $-6.629 E-07$ & $\begin{array}{l}-1.662 \mathrm{E}- \\
05 * * *\end{array}$ & -9.023E-05 \\
\hline Distance from Calgary & $1.047 \mathrm{E}-03^{* * *}$ & 0.006 & $-3.829 E-04$ & $-1.214 \mathrm{E}-04$ & $\begin{array}{l}1.152 \mathrm{E}- \\
03^{* * *}\end{array}$ & $6.254 \mathrm{E}-03$ \\
\hline \multicolumn{7}{|l|}{ Prior Investment Variables } \\
\hline Prior Planned Private Investment & $-1.200 \mathrm{E}-03 * * *$ & -0.007 & $-4.132 \mathrm{E}-04$ & $-1.310 \mathrm{E}-04$ & $\begin{array}{l}-1.210 \mathrm{E}- \\
03^{* * *}\end{array}$ & $-6.566 \mathrm{E}-03$ \\
\hline Prior Planned Public Investment & $-0.008 * * *$ & -0.045 & $-0.056 * * *$ & -0.018 & $\begin{array}{l}-5.637 \mathrm{E}- \\
03 * * *\end{array}$ & -0.031 \\
\hline $\begin{array}{c}\text { Prior Planned Private/Public } \\
\text { Investment }\end{array}$ & $-0.193^{* * *}$ & -1.088 & $-0.164 * * *$ & -0.052 & $-0.208 * * *$ & -1.131 \\
\hline \multirow{3}{*}{$\begin{array}{c}\text { Completed Actual Private } \\
\text { Investment } \\
\text { Completed Actual Public } \\
\text { Investment } \\
\text { Industry Effects }\end{array}$} & $9.099 \mathrm{E}-04 * * *$ & 0.005 & $-4.776 \mathrm{E}-04$ & $-1.514 \mathrm{E}-04$ & $\begin{array}{c}8.886 \mathrm{E}- \\
04 * * *\end{array}$ & 4.823E-03 \\
\hline & $-1.994 \mathrm{E}-02 * * *$ & -0.112 & $-1.059 \mathrm{E}-04$ & $-3.359 E-05$ & $\begin{array}{l}-2.033 \mathrm{E}- \\
02 * * *\end{array}$ & -0.110 \\
\hline & & & & & & \\
\hline Industry Dummy Variables? & \multicolumn{2}{|c|}{ Yes } & \multicolumn{2}{|c|}{ Yes } & \multicolumn{2}{|c|}{ Yes } \\
\hline \multicolumn{7}{|l|}{$\underline{\text { Model Diagnostics }}$} \\
\hline Number of Observations & \multicolumn{2}{|c|}{801} & \multicolumn{2}{|c|}{801} & \multicolumn{2}{|c|}{801} \\
\hline Adjusted $\mathrm{R}^{2}$ & \multicolumn{2}{|c|}{0.551} & \multicolumn{2}{|c|}{0.050} & \multicolumn{2}{|c|}{0.573} \\
\hline Chi-square Statistic & \multicolumn{2}{|c|}{$4607.396 * * *$} & \multicolumn{2}{|c|}{$30.815 * * *$} & \multicolumn{2}{|c|}{4843.310} \\
\hline
\end{tabular}









\begin{tabular}{|c|c|c|c|c|c|c|}
\hline & \multicolumn{2}{|c|}{$\begin{array}{c}\text { Model } 7 \\
\text { Population }<5,000\end{array}$} & \multicolumn{2}{|c|}{$\begin{array}{c}\text { Model } 8 \\
\text { Population }<1,000\end{array}$} & \multicolumn{2}{|c|}{$\begin{array}{c}\text { Model } 9 \\
\text { Population }<500\end{array}$} \\
\hline & Coefficient & Marginal Effect & Coefficient & Marginal Effect & Coefficient & Marginal Effect \\
\hline $\begin{array}{c}\text { Constant } \\
\text { Demographic Variables }\end{array}$ & $-1.114^{* * *}$ & -5.813 & $-1.249 * * *$ & -7.199 & $-2.103 * * *$ & -11.446 \\
\hline Non-SuperNet Community & $0.200^{* * *}$ & 1.046 & $0.419 * * *$ & 2.415 & $0.441^{* * *}$ & 2.403 \\
\hline Population & $\begin{array}{l}-2.287 \mathrm{E}- \\
04 * * *\end{array}$ & $-1.194 \mathrm{E}-03$ & $\begin{array}{c}3.126 \mathrm{E}- \\
04 * * *\end{array}$ & $1.802 \mathrm{E}-03$ & $-2.703 E-04$ & $-1.471 \mathrm{E}-03$ \\
\hline $\begin{array}{c}\text { Distance from Calgary } \\
\text { Prior Investment Variables }\end{array}$ & $\begin{array}{l}3.196 \mathrm{E}- \\
04 * * *\end{array}$ & $1.668 \mathrm{E}-03$ & $\begin{array}{c}1.738 \mathrm{E}- \\
04^{* * *}\end{array}$ & $1.002 \mathrm{E}-03$ & $2.022 \mathrm{E}-04^{* *}$ & $1.101 \mathrm{E}-03$ \\
\hline Prior Planned Private Investment & $-0.029 * * *$ & -0.149 & $-0.019 * * *$ & -0.110 & $-0.036 * * *$ & -0.199 \\
\hline Prior Planned Public Investment & $0.203^{* * *}$ & 1.059 & $0.501^{* * *}$ & 2.886 & $0.545^{* * *}$ & 2.965 \\
\hline $\begin{array}{c}\text { Prior Planned Private/Public } \\
\text { Investment }\end{array}$ & 0.042 & 0.221 & -1.312 & -7.565 & -1.226 & -6.674 \\
\hline $\begin{array}{c}\text { Completed Actual Private } \\
\text { Investment }\end{array}$ & $9.161 \mathrm{E}-04^{*}$ & 4.782E-03 & $1.298 \mathrm{E}-03^{* *}$ & 7.479E-03 & $5.044 \mathrm{E}-04$ & $2.745 E-03$ \\
\hline $\begin{array}{c}\text { Completed Actual Public } \\
\text { Investment } \\
\text { Industry Effects }\end{array}$ & $0.035^{* * *}$ & 0.185 & $0.052^{* * *}$ & 0.299 & $0.235^{* * *}$ & 1.277 \\
\hline Industry Dummy Variables? & & tes & & es & & es \\
\hline Model Diagnostics & \multirow{2}{*}{\multicolumn{2}{|c|}{715}} & \multirow{2}{*}{\multicolumn{2}{|c|}{559}} & \multirow{2}{*}{\multicolumn{2}{|c|}{536}} \\
\hline Number of Observations & & & & & & \\
\hline Adjusted $\mathrm{R}^{2}$ & \multicolumn{2}{|c|}{0.372} & \multicolumn{2}{|c|}{0.252} & \multicolumn{2}{|c|}{0.163} \\
\hline Chi-square Statistic & \multicolumn{2}{|c|}{$1281.014^{* * *}$} & \multicolumn{2}{|c|}{$635.684^{* * *}$} & \multicolumn{2}{|c|}{$188.191^{* * *}$} \\
\hline Loglikelihood & \multicolumn{2}{|c|}{-1080.028} & \multicolumn{2}{|c|}{-944.305} & \multicolumn{2}{|c|}{-483.708} \\
\hline $\begin{array}{l}\text { Partial derivatives of expected } \\
\text { value with respect to the vector } \\
\text { of characteristics computed at } \\
\text { the means of the variables. } \\
\text { Estimated value of E[y] } \\
\text { computed at the means is } \\
\text { (Can\$ millions): }\end{array}$ & \multicolumn{2}{|c|}{5.219} & & 764 & \multicolumn{2}{|c|}{5.443} \\
\hline
\end{tabular}




\begin{tabular}{|c|c|c|c|c|c|c|}
\hline \multicolumn{7}{|c|}{$\begin{array}{l}\text { Table 5. (Continued) } \\
\text { Panel C. SubSamples of Communities by Population and Distance (>150km) from Major Cities }\end{array}$} \\
\hline & \multirow{2}{*}{\multicolumn{2}{|c|}{$\begin{array}{c}\text { Model } 10 \\
>150 \mathrm{Km} \text { from Calgary and } \\
>150 \mathrm{Km} \text { from Edmonton, and } \\
\text { all communities (Maximum } \\
\text { Population in range }=66,035 \text { ) }\end{array}$}} & \multirow{2}{*}{\multicolumn{2}{|c|}{$\begin{array}{c}\text { Model 11 } \\
>150 \mathrm{Km} \text { from Calgary and } \\
>150 \mathrm{Km} \text { from Edmonton, } \\
\text { Population }<30,000\end{array}$}} & \multirow{2}{*}{\multicolumn{2}{|c|}{$\begin{array}{c}\text { Model } 12 \\
>150 \mathrm{Km} \text { from Calgary and }>150 \\
\text { Km from Edmonton, Population } \\
<10,000\end{array}$}} \\
\hline & & & & & & \\
\hline & Coefficient & Marginal Effect & Coefficient & Marginal Effect & Coefficient & Marginal Effect \\
\hline \multirow{2}{*}{$\begin{array}{c}\text { Constant } \\
\text { Demographic Variables }\end{array}$} & $-1.617 * * *$ & -13.574 & $-1.285^{* * *}$ & -9.875 & $-1.028 * * *$ & -7.004 \\
\hline & & & & & & \\
\hline \multirow{4}{*}{$\begin{array}{c}\text { Non-SuperNet Community } \\
\text { Population } \\
\text { Distance from Calgary } \\
\text { Prior Investment Variables }\end{array}$} & $-0.531 * * *$ & -4.462 & $0.106^{* * *}$ & 0.812 & $0.082^{* * *}$ & 0.557 \\
\hline & $\begin{array}{l}7.775 \mathrm{E}- \\
05^{* * *}\end{array}$ & $6.527 \mathrm{E}-04$ & $\begin{array}{l}8.229 \mathrm{E}- \\
05^{* * *}\end{array}$ & $6.322 \mathrm{E}-04$ & $-2.574 \mathrm{E}-05^{*}$ & $-1.754 \mathrm{E}-04$ \\
\hline & $\begin{array}{l}\text { 4.963E- } \\
04 * * *\end{array}$ & 4.166E-03 & $\begin{array}{l}5.500 \mathrm{E}- \\
04 * * *\end{array}$ & 4.225E-03 & $\begin{array}{l}\text { 4.253E- } \\
04^{* * *}\end{array}$ & 2.898E-03 \\
\hline & & & & & & \\
\hline \multirow{6}{*}{$\begin{array}{c}\text { Prior Planned Private Investment } \\
\text { Prior Planned Public Investment } \\
\text { Prior Planned Private/Public } \\
\text { Investment } \\
\text { Completed Actual Private } \\
\text { Investment } \\
\text { Completed Actual Public } \\
\text { Investment } \\
\text { Industry Effects }\end{array}$} & $-0.004 * * *$ & -0.031 & $-0.006 * * *$ & -0.046 & $-0.019 * * *$ & -0.131 \\
\hline & $0.198 * * *$ & 1.662 & $0.607 * * *$ & 4.664 & $0.422 * * *$ & 2.872 \\
\hline & $0.299 * * *$ & 2.510 & -0.617 & -4.738 & -0.341 & -2.321 \\
\hline & $\begin{array}{l}1.197 \mathrm{E}- \\
03 * * *\end{array}$ & $1.005 \mathrm{E}-02$ & $\begin{array}{c}8.492 \mathrm{E}- \\
04 * * *\end{array}$ & $6.524 \mathrm{E}-03$ & $8.600 \mathrm{E}-04$ & 5.859E-03 \\
\hline & $-0.242^{* * *}$ & -2.036 & $-0.200 * * *$ & -1.540 & $-0.192 * * *$ & -1.307 \\
\hline & & & & & & \\
\hline Industry Dummy Variables? & \multicolumn{2}{|r|}{ Yes } & \multicolumn{2}{|c|}{ Yes } & \multicolumn{2}{|c|}{ Yes } \\
\hline \multirow{6}{*}{$\begin{array}{c}\text { Model Diagnostics } \\
\text { Number of Observations } \\
\text { Adjusted } \mathrm{R}^{2} \\
\text { Chi-square Statistic } \\
\text { Loglikelihood } \\
\text { Partial derivatives of expected } \\
\text { value with respect to the vector } \\
\text { of characteristics computed at } \\
\text { the means of the variables. } \\
\text { Estimated value of E[y] } \\
\text { computed at the means is } \\
\text { (\$Can millions): }\end{array}$} & \multirow{2}{*}{\multicolumn{2}{|c|}{440}} & \multirow{2}{*}{\multicolumn{2}{|c|}{435}} & \\
\hline & & & & & \multicolumn{2}{|c|}{430} \\
\hline & \multicolumn{2}{|c|}{0.618} & \multicolumn{2}{|c|}{0.488} & & 151 \\
\hline & \multicolumn{2}{|c|}{$2929.102 * * *$} & \multicolumn{2}{|c|}{$1406.325^{* * *}$} & \multicolumn{2}{|c|}{$1149.658 * * *$} \\
\hline & \multirow{2}{*}{\multicolumn{2}{|c|}{-903.677}} & \multicolumn{2}{|c|}{-737.843} & \multicolumn{2}{|c|}{-699.885} \\
\hline & & & \multicolumn{2}{|c|}{7.683} & \multicolumn{2}{|c|}{6.813} \\
\hline
\end{tabular}

